\title{
Engine Performance and Emission Studies by Application of Nanoparticles and Antioxidants as Additives in Biodiesel Blends
}

\author{
Siddavatam Naresh Kumar Reddy*, Mohmad Marouf Wani \\ Department of Mechanical Engineering, National Institute of Technology, Srinagar 190006, India
}

Corresponding Author Email: nareshkumar_2017@nitsri.net

https://doi.org/10.18280/rcma.303-408

Received: 9 February 2020

Accepted: 21 May 2020

\section{Keywords:}

additives, antioxidants, biodiesel, diesel, emissions, nano particles, performance

\begin{abstract}
The present paper examines the effects of different nanoparticles and antioxidant additives blended with biodiesel on a CI engine's performance and emission parameters. Though, higher density, lower heating value, and viscosity are inherent drawbacks while rising specific fuel consumption and $\mathrm{NO}_{\mathrm{x}}$ emissions restrict biodiesel uses in engines. To overcome the limitations of biodiesel, additives of nanoparticles and antioxidants are various materials that play a distinct role in mitigating the drawbacks of biodiesel. Antioxidants blended with biodiesel were noticed to be active in diminishing the $\mathrm{NO}_{\mathrm{x}}$ emission by trapping free radicals, decomposing peroxides, and disrupting the chain propagating reactions. Biodiesel blends with nanoparticles were enhanced the engine performance and emission parameters compared to neat biodiesel blends because of higher calorific value, high surface to volume ratio, and high thermal conductivity properties of nanoparticles. Five different Diesel, B20, B20CO, B20AO, and B20AOCO test fuel blends to prepared for this investigation. It concluded that B20AOCO additive fuel showed high BTHE and reduced BSFC, $\mathrm{HC}, \mathrm{NO}_{\mathrm{x}}$, and $\mathrm{CO}$ emissions on the $\mathrm{CI}$ engine compared to other fuel blends.
\end{abstract}

\section{INTRODUCTION}

The need for petroleum products as fuel usually in the transport industry is growing daily due to the growing population of the earth. Today's air transport is rising, mainly due to the high population density in South Asia. Air transport uses petroleum products as fuel, while demand for fossil fuels will go on increases. It mainly influences the economic crisis of nations with fewer crude oil reserves. It releases more harmful environmental emissions, leads to health issues of population and air quality.

Somehow to replace alternative fuels to reduce pollution. These are sustainable and fewer emissions are released compared to fossil fuels. High cost and viscosity were the main limitations of edible oils as compared to fossil fuels. The best approach is the technique of transesterification to avoid density and viscosity problems of vegetable oils. This process raises biodiesel costs because chemicals and heat inputs are needed. Some research reports revealed that there were low heating value and high $\mathrm{NO}_{\mathrm{x}}$ emissions compared to fossil fuels after the transesterification process $[1,2]$.

Agarwal [3] conducted experiments in compression ignition engines operating straight cooking oils. The results revealed that, due to high viscosity and density, it produces atomization problems, fuel filter clogging, and incomplete combustion in diesel engines. Chong et al. [4] explored the effects of diesel engines by adding oxygenated additives in palm biodiesel. It observed that a delay in ignition gives to the lower pressure of the cylinder and further been a rise in BTHE and $\mathrm{CO}_{2}$ emissions.

Lesnik et al. [5] examined biodiesel injection properties in the CI engine. This investigation reported that advancing injection timing raised the cylinder pressure, decreased CO emissions, and EGT but higher $\mathrm{NO}_{\mathrm{x}}$ emissions. Uyumaz [6] studied the impact of different concentrations of biodiesel in a diesel engine. The obtained results were BTHE decreases of $\mathrm{B} 10$ biodiesel and rise $\mathrm{NO}_{\mathrm{x}}$ emissions of $22.1 \%$ with a B30 biodiesel blend.

Using different additives mixed with biodiesel, Rashedul et al. [7] examined the effects of performance, emissions, and combustion in CI engine. The results obtained were to reduce viscosity and density and rise volatile nature as correlated to biodiesel by using oxygenated additives in biodiesel.

Moreover, several examinations reported that when the CI engine operated with no modifications and biodiesel blends, additives were used as fuel enhanced performance and fewer emissions. They further said that better reduction emissions somewhat improve the diesel engine's performance using nano additives in biodiesel. Because of nano additives have high calorific value and surface to volume ratio. Antioxidants blended with biodiesel were noticed to be active in diminishing the $\mathrm{NO}_{\mathrm{x}}$ emission by trapping free radicals, decomposing peroxides, and disrupting the chain propagating reactions.

Kao et al. [8] conducted experiments on CI engine by blending aluminium nanoparticles in diesel fuel. The obtained results of aluminium nanoparticles added fuel gives reduce $\mathrm{BSFC}$, soot, and $\mathrm{NO}_{\mathrm{x}}$ emissions correlated to diesel at speeds of below $1800 \mathrm{rpm}$ in a diesel engine.

Kannan et al. [9] studied the effects of ferric chloride nanoparticles additive blended with WCPOME on a diesel engine. The results reported reduced BSFC and increased 
BTHE while FBC blended with biodiesel as correlated to conventional diesel as a fuel. Low $\mathrm{NO}_{\mathrm{x}}$ emissions when adding FBC additive with diesel but slightly increase $\mathrm{CO}_{2}$ emissions as related to diesel.

Varatharajan et al. [10] studied the effects of different antioxidants blended with jatropha biodiesel as fuel on a CI engine. The results revealed that BSFC value reduced by JOME blended with PPDA and EDA antioxidants over other antioxidants added with JOME as correlated to biodiesel.

Senthur Prabu et al. [11] examined the impacts of WCOME blended with BHT and n-butanol antioxidants on a CI engine. The obtained results reduced $\mathrm{CO}$ and slightly increased $\mathrm{NO}_{x}$ emissions by using WCOME with antioxidants as correlated to conventional diesel.

Velmurugan et al. [12] investigated the effects of antioxidants blended with mango biodiesel as fuel on a CI engine. The obtained results reduced $\mathrm{NO}_{\mathrm{x}}$ emissions by using antioxidants with biodiesel but slightly raised UBHC, smoke, and $\mathrm{CO}$ emissions contrasted to biodiesel.

Previous studies outlined that low calorific value and high $\mathrm{NO}_{\mathrm{x}}$ emissions limit the use of biodiesel in the diesel engine. Previous research studies recommended that biodiesel blended with nanoparticles would improve engine performance while resulting in a notable reduction in engine exhaust emissions expect carbon dioxide. Previous research studies indicated that adding antioxidants with biodiesel would improve engine performance while decreasing $\mathrm{NO}_{\mathrm{x}}$ emissions but slightly increasing other emissions.

Previous studies summarized that biodiesel blends with antioxidants and nanoparticles showed more advantages than its neat form. The influences of biodiesel blends with multiple additives on a CI engine were discussed in a few studies. Therefore, the present study compares the effects on a CI engine with antioxidants and nanoparticles added with biodiesel blends contrasted with diesel. The current research focuses on the effects of a CI engine's performance and emissions parameters by use of JOME blends with cobalt oxide nanoparticles and DPPD antioxidants as additives.

\section{MATERIALS AND METHODS}

In this work, Jatropha oil procured from Super India Enterprises, Jaipur, India. Diesel purchased from a local market. DPPD antioxidant purchased from Loba Chemie Pvt. Ltd, Mumbai. Antioxidant specifications illustrated in Table 1. $\mathrm{Co}_{3} \mathrm{O}_{4}$ nanoparticles with a size of less than $100 \mathrm{~nm}$ procured by the Nano research lab. Table 2 displays the specifications of nanoparticles.

\subsection{Preparation of fuel blends}

Alkaline transesterification process used to make JOME by use of raw jatropha oil. The primary step of JOME is methoxide solution. It is made by adding $25 \%$ methanol and $1 \%$ sodium hydroxide by volume with a magnetic stirrer. After heat crude jatropha oil up to $65^{\circ} \mathrm{C}$, it then added a methoxide solution into heated oil up to 60 minutes with the aid of ultrasonicator. Now separate the oil into a beaker. After 24 hours, glycerol settles down in a beaker due to high density and the upper part of a glass beaker was crude biodiesel. After separate the crude biodiesel with glycerol and then hot distilled water used to wash crude biodiesel. Now crude biodiesel heats up to $100^{\circ} \mathrm{C}$ to remove water content in crude biodiesel, and the next obtained fuel is biodiesel. The preparation of test fuel blends with antioxidant and nanoparticle additives by use of ultrasonicator. ASTM standards are used to find out test fuel blend properties that are shown in Table 3.

\subsection{Experimental setup}

The engine setup demonstrated in Figure 1. The engine test rig was computerized single cylinder variable compression ratio (VCR) CI engine with a hydraulic dynamometer. Test rig specifications illustrated in Table 4. The engine setup Incorporated with the Data Acquisition System (DAS) were the various digital load sensors, fuel measurement, airflow rate, crank angle location, and cylinder pressure sensors. To determine the performance and emission parameters of a CI engine with use of engine soft software. To measure the exhaust emissions of $\mathrm{HC}, \mathrm{CO}, \mathrm{CO}_{2}, \mathrm{NO}_{x}$, and $\mathrm{O}_{2}$ by the use of a multi-gas analyzer. Table 5 illustrates the resolution and range of different gasses. The engine tests performed with different loads on a computerized single cylinder VCR CI engine with a hydraulic dynamometer. Table 6 illustrated the accuracy and percentage of uncertainty for the measurements.

Table 1. Properties of antioxidant

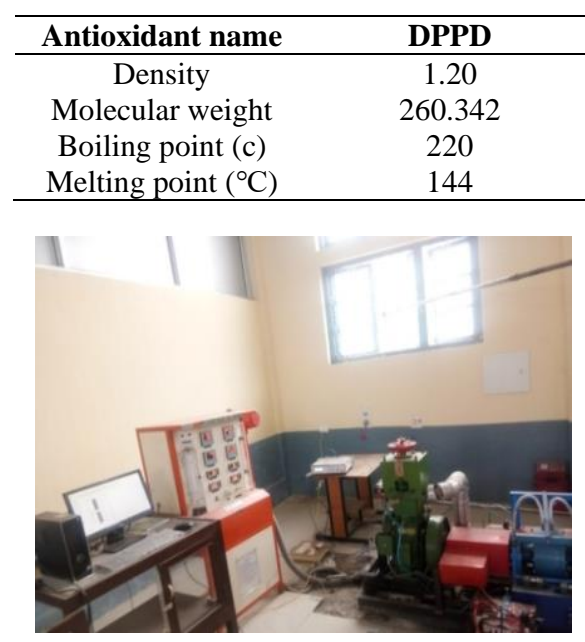

Figure 1. Experimental test rig

Table 2. Properties of nanoparticles

\begin{tabular}{|c|c|}
\hline Molecular formula & $\mathrm{Co}_{3} \mathrm{O}_{4}$ \\
\hline Molecular weight & 74.9326 \\
\hline Appearance & Fine dark grey to black powder \\
\hline Density $\left(\mathrm{g} / \mathrm{cm}^{3}\right)$ & 6.11 \\
\hline Boiling point $\left({ }^{\circ} \mathrm{C}\right)$ & 900 \\
\hline Melting point $\left({ }^{\circ} \mathrm{C}\right)$ & 895 \\
\hline Solubility in water & insoluble \\
\hline Chemical composition & $73.42 \%$ \\
\hline Oxygen & $26.57 \%$ \\
\hline
\end{tabular}


Table 3. Properties of test fuel blends

\begin{tabular}{cccccc}
\hline Properties & Diesel & Raw Jatropha oil & Jatropha Oil Methyl Ester (B100) & B20 Fuel & B20With additives \\
\hline Density $\left(\mathrm{kg}^{3} \mathrm{~m}^{3}\right)$ & 820 & $915-918$ & 872 & 842 & 834 \\
Viscosity $\left(\mathrm{mm}^{2} / \mathrm{s}\right)$ & 3.4 & 39.6 & 4.5 & 3.6 & 2.8 \\
Flash point $(\mathrm{K})$ & 321 & 493 & 367 & 340 & 332 \\
Fire point $(\mathrm{K})$ & 327 & 513 & 398 & 372 & 360 \\
Cetane Number & 48 & $38-42$ & 53 & 51 & 58 \\
Calorific value $(\mathrm{MJ} / \mathrm{kg})$ & 43.20 & 36.51 & 39.8 & 41.9 & 43.1 \\
\hline
\end{tabular}

Table 4. Engine specifications

\begin{tabular}{cc}
\hline Parameters & Specifications \\
\hline Basic engine & Kirloskar \\
Make & TECH-ED \\
Model & Four stroke single cylinder water cooled VCR diesel engine \\
Bore X Stroke & 80 X $110 \mathrm{~mm}$ \\
Rated power & up to $4 \mathrm{KW}$ \\
Capacity & $552 \mathrm{cc}$ \\
Connecting rod length & $234 \mathrm{~mm}$ \\
Speed (constant) & $1500 \mathrm{rpm}$ \\
Compression ratio & $12: 1$ to $20: 1$ \\
Piezo electric pressure sensor & 0 to 5000 psi \\
Dynamometer & Hydraulic dynamometer \\
\hline
\end{tabular}

Table 5. Specifications of resolution and range of the exhaust gas emissions

\begin{tabular}{ccc}
\hline Measurement & Resolution & Range \\
\hline $\mathrm{CO}$ & $0.001 \% \mathrm{Vol}$ & $0-9.99 \% \mathrm{Vol}$ \\
$\mathrm{HC}$ (propane) & $1 \mathrm{ppm}$ & $0-15000 \mathrm{ppm}$ \\
$\mathrm{CO}_{2}$ & $0.01 \% \mathrm{Vol}$ & $0-20 \% \mathrm{Vol}$ \\
$\mathrm{O}_{2}$ & $0.1 \% \mathrm{Vol}$ & $0-25 \% \mathrm{Vol}$ \\
$\mathrm{NO}_{\mathrm{x}}$ & $1 \mathrm{ppm} \mathrm{Vol}$ & $0-5000 \mathrm{ppm}$ \\
Engine RPM & $1 \mathrm{rpm}$ & $500-6000 \mathrm{rpm}$ \\
Oil Temperature & $1^{\circ} \mathrm{C}$ & $0-150^{\circ} \mathrm{C}$ \\
Lambda & 0.001 & $0.200-2.000 \%$ \\
\hline
\end{tabular}

Table 6. The accuracy and percentage of uncertainity for the measurements

\begin{tabular}{ccc}
\hline Measurements & Accuracy & Percentage uncertainty \\
\hline Engine speed & $\pm 2 \mathrm{rpm}$ & \pm 0.2 \\
Temperatures & $\pm 1^{\circ} \mathrm{C}$ & \pm 0.1 \\
Carbon monoxide & $\pm 0.02 \%$ & \pm 0.2 \\
Hydrocarbon & $\pm 10 \mathrm{ppm}$ & \pm 0.2 \\
Nitrogen oxides & $\pm 15 \mathrm{ppm}$ & \pm 0.2 \\
Burette fuel measurement & $\pm 2 \mathrm{CC}$ & \pm 1.5 \\
Crank angle encoder & $\pm 0.5 \mathrm{CA}$ & \pm 0.2 \\
Load & $\pm 1 \mathrm{~N}$ & \pm 0.2 \\
\hline
\end{tabular}

Table 7. Different types of blends with composition

\begin{tabular}{cc}
\hline Blend Name & Composition \\
\hline B0 & $0 \%$ Biodiesel + 100\% Diesel \\
B20 & $20 \%$ Biodiesel $+80 \%$ Diesel \\
B20AO & $20 \%$ Biodiesel $+80 \%$ Diesel +1500 PPM DPPD antioxidant \\
B20CO & $20 \%$ Biodiesel $+80 \%$ Diesel +60 PPM Co3 $\mathrm{O}_{4}$ nanoparticles \\
B20AOCO & $20 \%$ Biodiesel $+80 \%$ Diesel +60 PPM Co $_{3} \mathrm{O}_{4}$ nanoparticles + 1500 PPM DPPD antioxidant \\
\hline
\end{tabular}

\section{RESULTS AND DISCUSSIONS}

This research shows the impacts on a diesel engine by blending cobalt oxide $\left(\mathrm{Co}_{3} \mathrm{O}_{4}\right)$ nanoparticles and $\mathrm{N}, \mathrm{N}$ diphenyl-1, 4 phenylenediamine (DPPD) antioxidants additives with biodiesel blends, as shown in Table7. The emission tests are conducted five times using a multi-gas analyzer and the average value of emission data used to draw graphs.

\subsection{Engine performance}

Figure 2 illustrates the BSFC values with and without the addition of additives in biodiesel. It observed that BSFC of $\mathrm{B} 20$ blend rises as compared to diesel and B20 blend with nano additives decreased as contrasted to B20 blend. B20AOCO 
showed low BSFC as correlated to other B20 blends, and it was approximately equal to diesel at full load. Biodiesel has a low calorific value of up to $10 \%$ as contrasted to diesel. B20 blend gave only $2 \%$ less $\mathrm{CV}$ value than conventional fuel, so most of the researchers used B20 blend as fuel on a CI engine. Biodiesel blend with additives increases the $\mathrm{CV}$ value of fuel blend because of high $\mathrm{CV}$, high surface to volume ratio, better air-fuel mixing, rapid evaporation, and atomization. Yet lower BSFC reported by use of biodiesel with additives as contrasted with biodiesel. Another reason for enhanced BSFC is the friction step-down quality of amines.

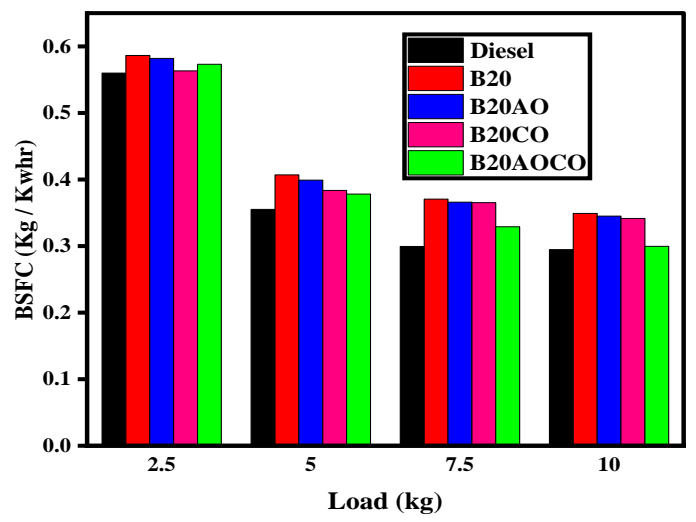

Figure 2. Brake Specific Fuel Consumption (BSFC) Vs Load

From Figure 3, B20AOCO showed high BTHE as correlated to other fuels at full load. Biodiesel showed complete and elegant combustion, which gave high brake thermal efficiency (BTHE) compared to diesel fuel. But it somewhat raises BTHE by adding nanoparticle and antioxidant additives into B20 blend. The BTHE of biodiesel blend with additives enhanced as contrasted to biodiesel, because of high $\mathrm{CV}$, high surface to volume ratio, better airfuel mixing, rapid evaporation, and atomization. Nanoparticles dispersed with biodiesel act as an oxidation catalyst, and it led the catalytic combustion resulting in higher BTHE contrasted with biodiesel.

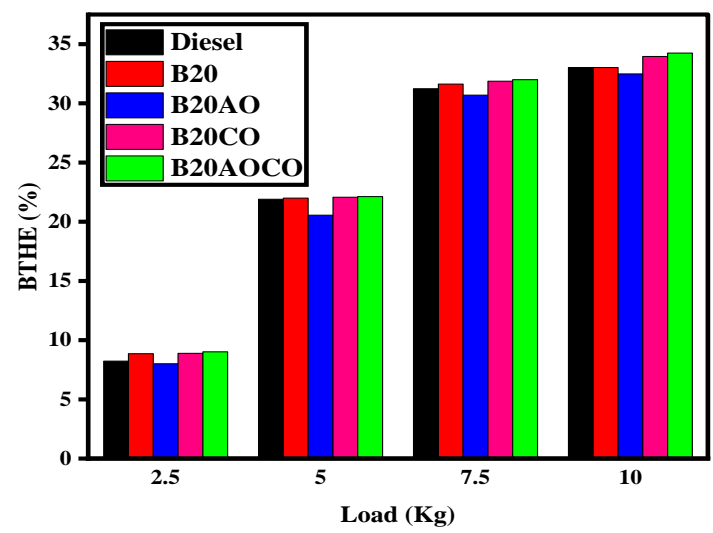

Figure 3. Brake Thermal Efficiency (BTHE) Vs Load

Figure 4 illustrated the EGT of test fuel blends varies brake power. If engine load increases, it raises the EGT of test fuel blends. The principal reason for the increases EGT of biodiesel blends was the higher BSFC of biodiesel to fulfil the engine's power requirement as contrasted with diesel. The EGT of B20 blends with additives decreased as correlated with other fuel blends. From Figure 2, B20AOCO blend showed better than the other blends. The EGT of B20 blends with additives decreased due to rapid evaporation and better atomization of fuel.

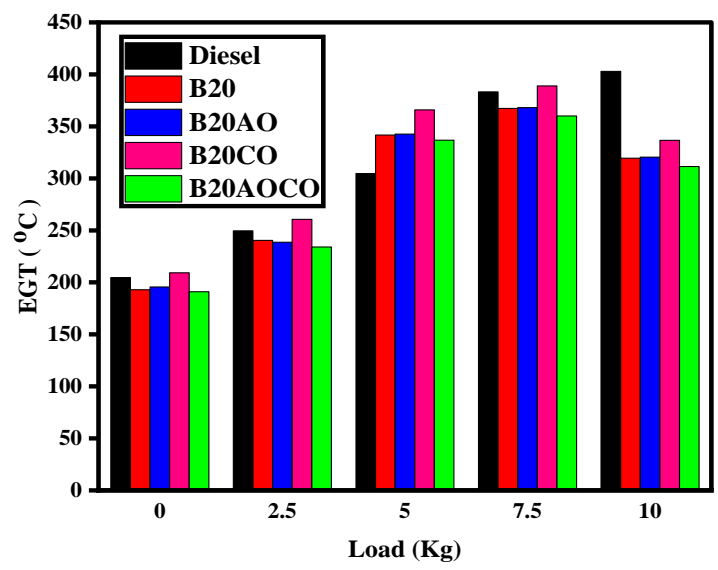

Figure 4. Exhaust Gas Temperature (EGT) Vs Load

\subsection{Engine emissions}

Figure 5 illustrated the carbon monoxide (CO) emissions of test fuel blends varies brake power. Lower injection pressure and incomplete combustion are significant reasons for the formations of $\mathrm{CO}$ emissions. Low $\mathrm{CO}$ emissions were obtained from B20AOCO fuel as correlated to other fuels. Biodiesel blends reduced $\mathrm{CO}$ emissions correlated to diesel because it contains oxygen molecules assured the complete combustion of fuel, which was further reduced by use of additives in biodiesel.

Lower injection pressure inside the cylinder, incomplete flame propagation, lower charge temperature, and a too rich or lean mixture are significant reasons for the formation of hydrocarbons (HC) emissions. Figure 6 illustrated the $\mathrm{HC}$ emissions of test fuel blends vary brake power. Low $\mathrm{HC}$ emissions were obtained from B20AOCO fuel as correlated to other fuels. Biodiesel blends reduced $\mathrm{HC}$ emissions correlated to diesel because it contains oxygen molecules assured the complete combustion of fuel, which was further reduced by use of additives in biodiesel.

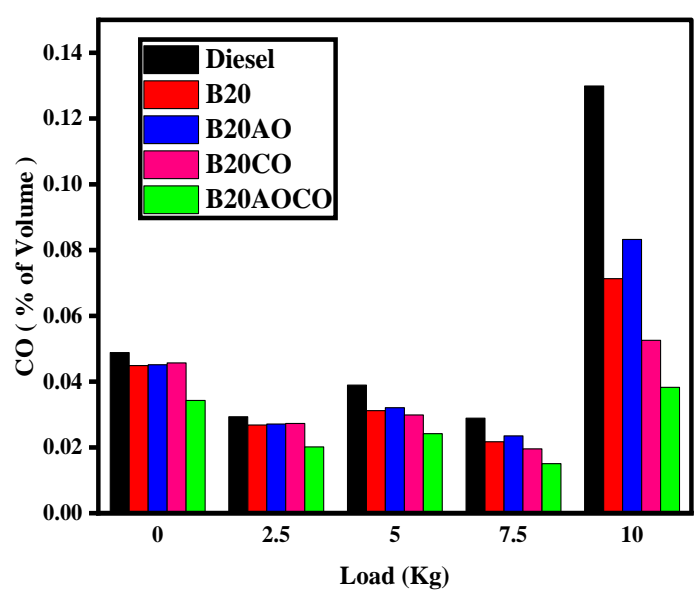

Figure 5. Carbon Monoxide (CO) Vs Load

$\mathrm{NO}_{\mathrm{x}}$ emissions development is dependent on volumetric efficiency, high combustion temperature, and combustion duration resulting from the high energy activation required for 
the reactions concerned. Biodiesel blends produced higher $\mathrm{NO}_{\mathrm{x}}$ emissions than diesel because of oxygen molecules in biodiesel. It creates higher combustion temperature inside the cylinder, leading to the strong covalent bond of nitrogen $\left(\mathrm{N}_{2}\right)$ reacts with free radicals, causing the generation of $\mathrm{NO}_{\mathrm{x}}$ emissions by the succeeding chemical reactions. From Figure 7, B20 fuel blend rises $\mathrm{NO}_{\mathrm{x}}$ emissions than diesel. B20 with additive blends showed a better reduction of $\mathrm{NO}_{\mathrm{x}}$ emissions than biodiesel blends and diesel. B20AOCO blend gave low $\mathrm{NO}_{\mathrm{x}}$ emissions contrasted with other blends. The key reason for the reduced $\mathrm{NO}_{\mathrm{x}}$ emissions was the antioxidants trap the free radicals and also it doesn't propagate the reaction of free radicals. Another reason for diminishing $\mathrm{NO}_{\mathrm{x}}$ emissions was nanoparticles act as a catalyst while the combustion process and avoided the conversion of $\mathrm{N}_{2}$ to nitric oxide radicals.

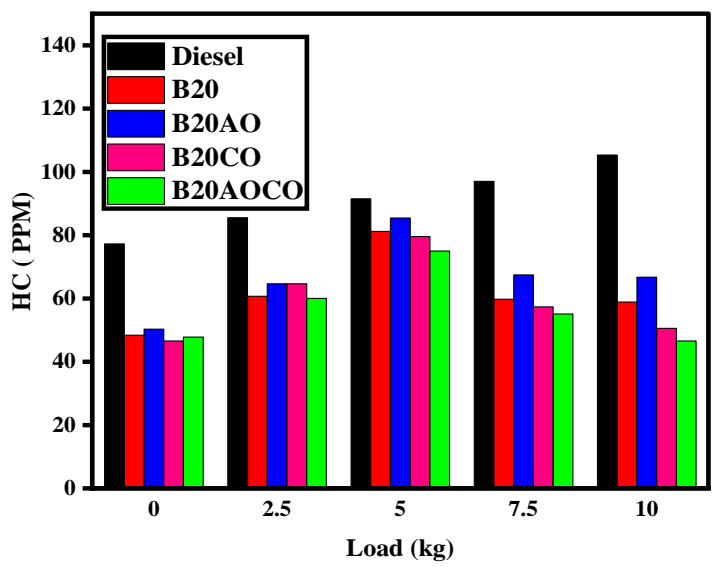

Figure 6. Hydrocarbons (HC) Vs Load

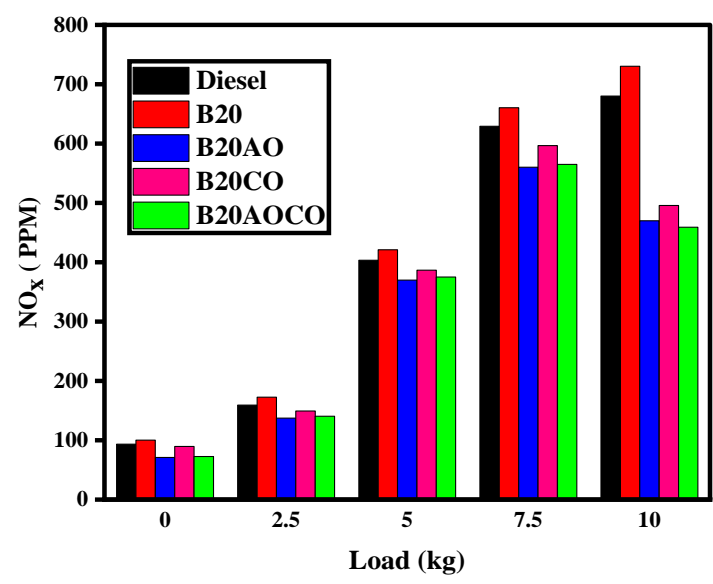

Figure 7. Nitrogen Oxides $\left(\mathrm{NO}_{\mathrm{x}}\right) \mathrm{Vs}$ Load

\section{CONCLUSIONS}

This experimental study reported that the effects of engine performance and emission parameters on a CI engine fuelled with jatropha biodiesel treated with cobalt oxide $\left(\mathrm{Co}_{3} \mathrm{O}_{4}\right)$ nanoparticles and $\mathrm{N}, \mathrm{N}$-diphenyl-1, 4 phenylenediamine (DPPD) antioxidant. The following conclusions could be drawn.

- It observed that BSFC of B20 blend rises as correlated to diesel and nano additives added with B20 blend decreased as contrasted to B20 blend. B20AOCO showed low BSFC as correlated to other B20 blends, and it was approximately equal to diesel at full load.

- Biodiesel gave complete and clean combustion, so it provided high brake thermal efficiency (BTHE) as contrasted to diesel. Although it somewhat raises BTHE by blended nanoparticle and antioxidant additives into B20 blend. B20AOCO showed high BTHE as correlated to other fuels at full load.

- EGT of B20AOCO blend showed better than the other blends. The EGT of B20 blends with additives decreased due to rapid evaporation and better atomization of fuel.

- B20AOCO fuel showed low HC emissions compare to other fuels. Biodiesel blends reduced $\mathrm{CO}$ emissions correlated to diesel because it contains oxygen molecules assured the complete combustion of fuel, which was further reduced by use of additives in biodiesel.

- Low CO emissions obtained from B20AOCO fuel as compared to other fuels. Biodiesel blends reduced $\mathrm{CO}$ emissions correlated to diesel because it contains oxygen molecules assured the complete combustion of fuel, which was further reduced by use of additives in biodiesel.

- B20AOCO fuel blend gave low NOx emissions contrasted with other blends. The key reason for the reduced NOx emissions was the antioxidants trap the free radicals and also it doesn't propagate the reaction of free radicals. Another reason for diminishing NOx emissions was nanoparticles act as a catalyst while the combustion process and avoided the conversion of $\mathrm{N} 2$ to nitric oxide radicals.

This paper concluded that by $\mathrm{B} 20 \mathrm{AOCO}$ additive fuel blend showed high BTHE and reduced BSFC, EGT, $\mathrm{HC}, \mathrm{NO}_{\mathrm{x}}$ and $\mathrm{CO}$ emissions on a $\mathrm{CI}$ engine as compared to other fuel blends.

\section{REFERENCES}

[1] Yuvarajan, D., Babu, D.M., BeemKumar, N., Kishore, A.P. (2017). Experimental investigation on the influence of titanium dioxide nanofluid on emission pattern of biodiesel in a diesel engine. Atmospheric Pollution Research, $9(1)$ : 47-52. https://doi.org/10.1016/j.apr.2017.06.003

[2] Ramadhas, A., Jayaraj, S., Muraleedharan, C. (2004). Use of vegetable oils as I.C. engine fuels - a review. Renewable Energy, 29(5): 727-742. https://doi.org/10.1016/j.renene.2003.09.008

[3] Agarwal, A.K. (2007). Biofuels (alcohols and biodiesel) applications as fuels for internal combustion engines. Progress in Energy and Combustion Science, 33: 233271. https://doi.org/10.1016/j.pecs.2006.08.003

[4] Chong, C.T., Jo-Han, N., Ahmad, S., Rajoo, S. (2015). Oxygenated palm biodiesel: Ignition, combustion and emissions quantification in a light-duty diesel engine. Energy Conversion Management, 101: 317-325. http://dx.doi.org/10.1016/j.enconman.2015.05.058

[5] Lešnik, L., Vajda, B., Žunič, Z., Škerget, L., Kegl, B. (2013). The influence of biodiesel fuel on injection characteristics, diesel engine performance, and emission formation. Applied Energy, 111: 558-570. https://doi.org/10.1016/j.apenergy.2013.05.010

[6] Uyumaz, A. (2018). Combustion, performance and emission characteristics of a DI diesel engine fueled with mustard oil biodiesel fuel blends at different engine loads. 
Fuel,

212:

https://doi.org/10.1016/j.fuel.2017.09.005

[7] Rashedul, H.K., Masjuki, H.H., Kalam, M.A., Ashraful, A.M., Rahman, A.S.M., Shahir, S.A. (2014). The effect of additives on properties, performance and emission of biodiesel fuelled compression ignition engine. Energy Conversion Management, 88: 348-64. https://doi.org/10.1016/j.enconman.2014.08.034

[8] Kao, M., Ting, C., Lin, B., Tsung, T. (2008). Aqueous aluminum nanofluid combustion in diesel fuel. Journal of Testing and Evaluation, 36(2): 186-190. https://doi.org/10.1520/JTE100579

[9] Kannan, G.R., Karvembu, R., Anand, R. (2011). Effect of metal based additive on performance emission and combustion characteristics of diesel engine fuelled with biodiesel. Applied Energy, 88(11): 3694-3703. https://doi.org/10.1016/j.apenergy.2011.04.043

[10] Varatharajan, K., Cheralathan, M., Velraj, R. (2011). Mitigation of $\mathrm{NO}_{\mathrm{x}}$ emissions from a jatropha biodiesel fuelled di diesel engine using antioxidant additives. Fuel, 90(8): 2721-2725. https://doi.org/10.1016/j.fuel.2011.03.047

[11] Prabu, S., Asokan, M.A., Roy, R., Francis, S., Sreelekh, M.K. (2017). Performance, combustion and emission characteristics of diesel engine fuelled with waste cooking oil bio-diesel/diesel blends with additives. Energy, 122:

638-648 https://doi.org/10.1016/j.energy.2017.01.119

[12] Velmurugan, K., Sathiyagnanam, A.P. (2016). Impact of antioxidants on $\mathrm{NO}_{\mathrm{x}}$ emissions from a mango seed biodiesel powered di diesel engine. Alexandria Engineering Journal, 55(1): 715-722. http://dx.doi.org/10.1016/j.aej.2015.10.004

\section{NOMENCLATURE}

BTHE brake thermal efficiency

\begin{tabular}{|c|c|}
\hline KW & kilowatts \\
\hline BSFC & brake specific fuel consumption \\
\hline $\mathrm{NO}_{\mathrm{x}}$ & nitrogen oxides \\
\hline $\mathrm{HC}$ & hydrocarbons \\
\hline UBHC & unburned hydrocarbons \\
\hline $\mathrm{O}_{2}$ & oxygen \\
\hline $\mathrm{CO}$ & carbon monoxide \\
\hline $\mathrm{CO}_{2}$ & carbon dioxide \\
\hline EGT & exhaust gas temperature \\
\hline CI & compression ignition \\
\hline $\mathrm{CN}$ & cetane number \\
\hline RPM & revolutions per minute \\
\hline WCPOME & waste cooking palm oil methyl ester \\
\hline FBC & fuel borne catalyst \\
\hline JOME & jatropha oil metyl ester \\
\hline EDA & Edaravone \\
\hline PPDA & P-Phenylenediamine \\
\hline BHT & butylated hydroxytoluene \\
\hline PPM & parts per millon \\
\hline WCOME & waste cooking oil methyl ester \\
\hline DPPD & $\mathrm{N}, \mathrm{N}$-diphenyl 1,4phenylenediamine \\
\hline $\mathrm{Co}_{3} \mathrm{O}_{4}$ & cobalt oxide \\
\hline $\mathrm{nm}$ & nanometers \\
\hline psi & pounds per square inch \\
\hline ASTM & american society fortesting and materials \\
\hline VCR & variable compression ratio \\
\hline DAS & data acquistion system \\
\hline B10 & $10 \%$ Biodiesel $+80 \%$ Diesel \\
\hline B20 & $20 \%$ Biodiesel + 80\% Diesel \\
\hline B30 & $30 \%$ Biodiesel $+80 \%$ Diesel \\
\hline $\mathrm{B} 20 \mathrm{CO}$ & $\begin{array}{l}20 \% \text { Biodiesel }+80 \% \text { Diesel + } 60 \text { PPM } \\
\mathrm{Co}_{3} \mathrm{O}_{4} \text { nanoparticles }\end{array}$ \\
\hline $\mathrm{B} 20 \mathrm{AO}$ & $\begin{array}{l}20 \% \text { Biodiesel }+80 \% \text { Diesel }+1500 \text { PPM } \\
\text { DPPD antioxidant }\end{array}$ \\
\hline B20AOCO & $\begin{array}{l}20 \% \text { Biodiesel }+80 \% \text { Diesel }+60 \mathrm{ppm} \\
\mathrm{Co}_{3} \mathrm{O}_{4} \text { nanoparticles }+1500 \text { PPM DPPD } \\
\text { antioxidant }\end{array}$ \\
\hline
\end{tabular}

